\title{
MAKSIM PERBUALAN DAN ELEMEN PENDIDIKAN DALAM PODCAST \#NOTAPIS
}

\author{
Indirawati ZAHID*1 \\ Muhammad Nasri SELAMAT ${ }^{2}$ \\ 1,2 Universiti Malaya, Kuala Lumpur, Malaysia \\ 1indirawati@um.edu.my \\ 2 m.nasri.selamat@gmail.com
}

Manuscript received 4 January 2021

Manuscript accepted 14 December 2021

*Corresponding author

https://doi.org/10.33736/ils.2909.2021

\begin{abstract}
ABSTRAK
Maksim perbualan (MP) yang diusulkan oleh Grice (1975) bertujuan memastikan sesuatu komunikasi dapat berlangsung dengan lancar apabila MP dipatuhi. Ini tidak berlaku dalam realiti dan dibuktikan dalam podcast \#NoTapis (\#NoTapis, 2020). \#NoTapis ialah satu temu bual dengan seorang doktor berkaitan COVID-19. Analisis ini mengaplikasikan metod kualitatif - muat turun, transkripi dan analisis teks. Analisis ini mempunyai dua objektif, iaitu pertamanya, mengenal pasti kepatuhan dan ketidakpatuhan MP; dan keduanya membincangkan faktor kepatuhan MP dan korelasinya dengan elemen pendidikan, iaitu domain kognitif dan afektif dalam taksonomi Bloom (1956). Objektif ini bertitik tolak daripada pandangan Gary (2020) bahawa terdapat kandungan podcast yang bersifat mendidik. Kepatuhan MP didapati berkorelasi dengan domain kognitif dan afektif. Korelasi pada domain kognitif berlaku pada semua aras kecuali aras 5 manakala bagi domain afektif, korelasi berlaku pada semua aras. Pematuhan MP didapati sentiasa berkorelasi dengan aras paling rendah kepada aras yang lebih tinggi. Ini bertepatan dengan penyataan bahawa pengajaran dan pembelajaran (PdP) merupakan satu proses. Dalam konteks podcast ini, doktor berperanan sebagai "guru" manakala pendengar podcast merupakan "pelajar".
\end{abstract}

Kata kunci: maksim perbualan; elemen pendidikan; podcast; COVID-19 


\title{
CONVERSATIONAL MAXIMS AND EDUCATIONAL ELEMENTS IN PODCAST \#NOTAPIS
}

\begin{abstract}
The conversational maxims (MP) proposed by Grice (1975) aims to ensure that communication can run smoothly when the MP are observed. This does not happen in reality and was proven in the \#NoTapis podcast (\#NoTapis, 2020). \#NoTapis is an interview with a doctor about COVID-19. This research's analysis applied qualitative methods - download, transcription and text analysis. The analysis' objectives were to identify the observance and non-observance of MP; and to discuss the observance of MP correlated to educational elements, i.e cognitive and affective domains in Bloom's (1956) taxonomy. The second objective is based on the Gary's (2020) view which stipulates that podcasts have educational content. The findings showed that the observance of MP correlated with cognitive and affective domains. Correlation in the cognitive domain occurs at all levels except on level 5 while for the affective domain correlation occurs at all levels. The observance of MP is found to always be correlated with the lowest level to the higher level of domain. These findings fits the statement that teaching and learning (PdP) is a process. In this podcast, the doctor act as the "teacher" while podcast listeners are the "students".
\end{abstract}

Keywords: conversational maxims; educational elements; podcast; COVDI-19

\section{Pendahuluan}

Podcast atau audio siar (Pusat Rujukan Persuratan Melayu, 2020) merupakan program audio yang sama seperti radio (Gary, 2020) dan popular digunakan oleh generasi Z, komuniti muda pada hari ini. Podcast diakses dengan menggunakan peranti yang sesuai dan perlu mempunyai akses Internet. Sesuai dengan peredaran masa dan kecanggihan teknologi, akses kepada podcast tidak terhad dalam kalangan generasi Z sahaja sebaliknya kebanyakan generasi yang lebih awal juga kini telah mengikuti perkembangan teknologi ini. Antara peranti yang lazim digunakan untuk mengikuti program audio ini ialah komputer, telefon misalnya Iphone, telefon Android, Ipad dan tablet. Podcast boleh didengar melalui pelayar web (web browser) seperti Chrome, Safari atau Microsoft Edge. Hal ini dilakukan di komputer atau pelayar web di telefon. Sementara di Iphone pula digunakan aplikasi podcasts Apple manakala di telefon Android digunakan aplikasi podcasts Google. Dengan kata lain, podcast merupakan antara salah satu medium penyebaran maklumat yang digunakan pada hari ini. Podcast ialah istilah yang terbentuk daripada kombinasi dua kata melalui proses blends (Crystal, 2008) atau portmanteau, iaitu kata ipod dan broadcast (Patterson, 2006).

Podcast kebanyakannya didapati dalam bentuk audio walau bagaimanapun terdapat juga podcast dalam bentuk video (Gary, 2020). Podcast dalam bentuk video dikenali dengan nama vodcast. Sehubungan dengan itu, penyataan Gary (2020) ini selari 
dengan definisi podcast oleh Dictionary.com (2020), iaitu fail rakaman audio atau video digital yang lazimnya merupakan sebahagian daripada siri yang mempunyai tema, boleh dimuat turun daripada laman web ke pemain media atau komputer. Menurut McGivern (2020) terdapat lima jenis podcast yang dinamakan berdasarkan ciri-cirinya, iaitu audio podcasts, video podcasts, enhanced podcasts, podcast novels dan pdf/ePub podcasts. Kandungan podcast bersifat menghiburkan, mendidik atau memberikan inspirasi kepada penggunanya dalam kehidupan yang berlatarbelakangkan aktiviti lain yang membosankan atau rutin kehidupan yang sama dan berulang (Gary, 2020). Kandungan podcast boleh dimuat turun, disimpan dan didengar atau ditonton pada bila-bila masa sahaja oleh penggunanya secara luar talian (offline).

Kandungan podcast yang mempunyai pelbagai sifat dan antaranya adalah bertujuan mendidik menjadi titik tolak kepada analisis maksim perbualan (MP) dan elemen pendidikannya dalam episod yang telah dikenal pasti, iaitu berkaitan COVID-19. MP dan elemen pendidikan didapati saling berkaitan kerana MP oleh Grice (1975) menekankan keberkesanan komunikasi bertujuan pencapaian objektif dan dalam konteks podcast yang dianalisis, objektif yang dirujuk ialah pendidikan berkaitan COVID19. Maklumat COVID-19 dalam medium ini disampaikan secara santai oleh hos podcast dengan mengambil kira maklumat penting yang perlu disampaikan kepada pendengarnya melalui penyediaan soalan-soalan berdasarkan papan cerita. Papan cerita mempunyai beberapa fungsi yang antara lainnya membantu penentuan parameter cerita dalam sumber yang ditentukan dalam tempoh yang ditetapkan, menentukan aturan, fokus cerita dan mengenal pasti medium yang akan digunakan bagi setiap satu bahagian cerita tersebut (Advanced Media Institute, 2020). Lanjutan itu, analisis perbualan yang bersifat soal jawab ini berfokus kepada kepatuhan maksim perbualan Grice (1975) yang dikorelasikan dengan taksonomi Bloom domain kognitif dan afektif (Anderson \& Krathwohl, 2001). Dalam konteks ini pendengar podcast merupakan "pelajar" yang mendapat pendidikan berkaitan topik COVID-19.

\section{Sorotan Kajian}

Prinsip kerjasama yang diusulkan oleh Grice (1975) bagi menandakan kualiti komunikasi telah dilakukan pada aspek kepatuhan dan ketidakpatuhan MP dengan menggunakan pelbagai korpus. Tujuannya adalah untuk membincangkan faktor-faktor yang mempengaruhi kepatuhan dan ketidakpatuhan yang berlaku. Sungguhpun korpus analisis yang digunakan pelbagai, dapatan tidak memperlihatkan perbezaan yang signifikan. Kepatuhan MP sering kali berasosiasi dengan isu yang diperkatakan dalam sesi bual bicara, forum dan sebagainya yang dikawal oleh moderator dengan kewujudan papan cerita dalam sesuatu rancangan. Sebaliknya, dapatan ketidakpatuhan MP pula lebih bersifat rencam antaranya atas faktor mempunyai agenda tertentu, kesantunan dan sebagainya. Oleh itu aspek ini menjadi tumpuan kajian antaranya oleh Muhammad dan Karim (2019), Aisya dan Fitrawati (2019), Hamani dan Puluhulawa (2019), Awwad et al. (2019), Hasan et al. (2020) dan Zahid (2020). 
Muhammad dan Karim (2019) melakukan kajian yang bermatlamat mendapatkan jawapan kepada kaitan kepatuhan dan ketidakpatuhan MP dalam bahasa. Dua korpus temu bual yang berbeza digunakan, iaitu set pertama bertemakan politik dan keduanya, bertemakan hiburan. Temu bual pertama melibatkan tokoh Barrack Obama dan Donald Trump manakala data hiburan melibatkan Lady Gaga dan Brad Pitt. Dapatan kajian ini memperlihatkan kepatuhan dan ketidakpatuhan MP berlaku dalam kedua-dua korpus. Walau bagaimanapun kepatuhan MP didapati lebih banyak berlaku dalam temu bual bertemakan hiburan sebaliknya yang bertemakan politik. Ketidakpatuhan maksim kuantiti dan cara dalam temu bual politik berpunca daripada agenda rahsia dan keengganan ahli politik tersebut menjawab setiap pertanyaan dengan lengkap dan jelas sepertimana kehendak soalan.

Penggunaan korpus temu bual ahli politik kelihatan menjadi minat para pengkaji dan ini tidak terkecuali dengan Aisya dan Fitrawati (2019). Kajian yang dilakukan berfokus kepada pelanggaran MP oleh ahli politik dalam dua episod temu bual. Tujuan kajian adalah untuk mengenal pasti jenis dan faktor pelanggaran MP yang disebabkan oleh ujaran tak langsung. Dapatan kajian menemukan bahawa ahli politik cenderung melakukan pelanggaran maksim kuantiti diikuti dengan maksim cara bertitik tolak daripada dua alasan utama, iaitu mempertingkat kekuatan mesej dan kesantunan.

Korpus filem juga didapati antara korpus yang popular dikaji. Hamani dan Puluhulawa (2019) serta Hasan et al. (2020) misalnya mengunakan korpus filem "Kungfu Panda" dan "Dayang Senandong" dalam kajian mereka. Kedua-dua kajian ini memperlihatkan dapatan yang sama, iaitu pelanggaran MP berlaku dalam kedua-dua filem yang dikaji. Pelanggaran maksim kuantiti cenderung dilakukan dalam filem "Kungfu Panda" dengan dua tujuan, iaitu pertamanya pemberian maklumat melebihi keperluan bagi tujuan kejelasan maklumat dan keduanya berlaku kekurangan maklumat yang diberikan. Sementara dapatan kajian dalam filem "Dayang Senandong", pelanggaran MP disebabkan oleh nilai kehalusan berbahasa masyarakat Melayu, iaitu dengan penggunaan implikatur.

Sementara itu, kajian oleh Awwad et al. (2019) memperlihatkan kelainan, iaitu mengkaji dapatan kajian oleh para pengkaji sebelumnya berkaitan aplikasi pencabulan MP. Rumusan yang diperoleh, ketidakpatuhan MP berlaku dalam konteks kehidupan seperti sastera, agama, humor dan jenaka secara lisan, konteks bertulis dan konteks lain berpunca daripada pengabaian keaslian, jumlah, kesesuaian dan cara maklumat yang disediakan pada setiap giliran perbualan.

Terkini, kajian oleh Zahid (2020) menggunakan data temu bual dengan seorang mantan ahli politik berkaitan faktor kemenangan sebuah parti politik dalam pilihan raya. Kajian ini menemukan ketidakpatuhan MP yang bertujuan memberikan penjelasan, membuat penegasan, melahirkan rasa tidak puas hati atau marah tentang sesuatu isu dan berkata benar. Ketidakpatuhan MP ini didapati tidak menjejaskan keberkesanan komunikasi berdasarkan lima faktor, iaitu latar belakang khalayak, isu semasa, budaya, konteks komunikasi dan wibawa interlokutor.

Kepelbagaian data yang analisis memaparkan kepatuhan serta ketidakpatuhan dalam realiti kehidupan dan penemuan ini didapati hampir sama dalam semua kajian. 
Oleh itu, objektif dan dapatan seperti ini memperlihatkan berlakunya jurang kajian MP yang mengaitkannya dengan aspek lain. Lanjutan itu, kajian yang dilakukan ini cuba merapatkan jurang yang berlaku dengan menganalisis kepatuhan MP dan korelasinya dengan taksonomi Bloom (1956), domain kognitif dan afektif (Krathwohl et al., 1964) dalam podcast yang bersifat mendidik.

\section{Objektif Kajian}

Analisis yang dilakukan ini mempunyai dua objektif:

1. Mengenal pasti kepatuhan dan ketidakpatuhan maksim perbualan dalam podcast \#NoTapis.

2. Membincangkan faktor kepatuhan maksim perbualan dan korelasinya dengan elemen pendidikan dalam podcast \#NoTapis.

\section{Bahan Kajian}

Kajian ini menganalisis podcast \#NoTapis yang disiarkan di platform Spotify dan diterbitkan oleh Berita Harian Singapura (BHS). Podcast \#NoTapis mula dilancarkan pada 21 Jun 2019 (SPH Media Solutions, 2019). Penerbitan podcast ini bertujuan mendekati komuniti muda Melayu dan berbicara di hati mereka tentang topik yang berpusat di sekitar minat masyarakat Melayu termasuk agama, gaya hidup dan wawancara selebriti. \#NoTapis mempunyai sejumlah episod yang disiarkan pada tahun 2020. Episod yang menjadi fokus analisis ialah episod yang berjudul "Dr Elly Sabrina - Kupas Wabak Koronavirus Wuhan". Episod ini disiarkan pada 1 Februari 2020 dan berdurasi 68 minit. Episod ini dipilih atas faktor isu semasa dan medium baharu yang digunakan dalam mendekati anggota masyarakat. Episod ini melibatkan soal jawab dua orang hos dan seorang tetamu jemputan, iaitu E yang merupakan seorang doktor. Analisis berfokus kepada ujaran E dalam struktur isi dan perbincangan dapatan hanya terhad kepada tiga peristiwa bahasa. Pengehadan ini dilakukan atas dua faktor, iaitu kerana struktur dan kesinambungan maklumat memperlihatkan kesamaan dapatan aspek pematuhan dan ketidakpatuhan dalam kajian-kajian lain sebelum ini dan bertujuan membuka ruang perbincangan pada sisi yang berkaitan korelasi pematuhan MP dengan elemen pendidikan (Gary, 2020). Bagi tujuan keseragaman, istilah COVID-19 digunakan, iaitu nama yang diberikan oleh World Health Organization (WHO) pada 11 Februari 2020 (World Health Organization, 2020a). Hal ini bertitik tolak daripada julat perbezaan tempoh semasa podcast ini berlangsung dan semasa analisis ini dilakukan, iaitu sebelum nama khusus diberikan kepada penyakit ini. COVID-19 diisytiharkan sebagai pandemik oleh WHO pada 11 Mac 2020 (World Health Organization, 2020b). 


\section{Metodologi}

Kajian ini mengaplikasikan metod kualitatif. Metod ini mencakupi muat turun, ulang dengar, transkripsi dan analisis teks. Perincian metod dipaparkan dalam Rajah 1 berikut:

\section{Rajah 1}

Metod kajian

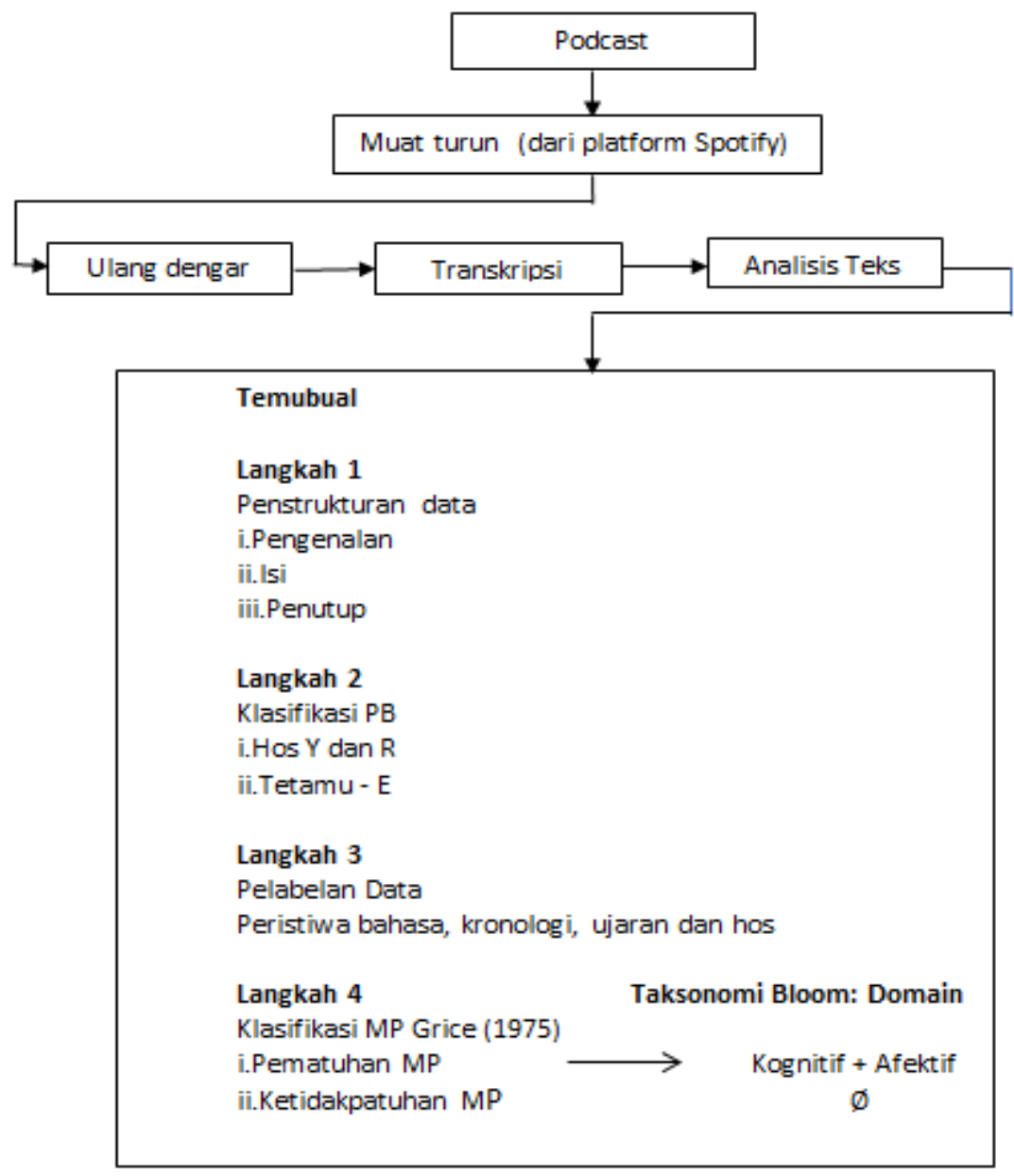

Petunjuk

$\longrightarrow$ Korelasi $\quad \varnothing \quad$ tidak berkenaan

Rincian pelabelan data ujaran dengan kod pada Langkah 3, misalnya PB2IYU3I merujuk kepada PB, peristiwa bahasa kedua; I, struktur isi; Y, hos bernama Suhaimi; dan U, ujaran; dan angka, bilangan ujaran berdasarkan kronologi. Manakala klasifikasi MP Grice 
(1975) dalam Langkah 4 ialah pelabelan kod bagi kepatuhan MP, iaitu K bagi kuantiti; Q bagi kualiti; $\mathrm{H}$, bagi hubungan; dan $\mathrm{C}$, bagi cara. Sementara itu, ketidakpatuhan MP dilabelkan dengan $\mathrm{L}$ sebagai pelanggaran; $\mathrm{V}$, pencabulan; $\mathrm{O}$, pilihan keluar; J, penjejasan dan G, penggantungan. Korelasi MP dan Taksonomi Bloom hanya berfokus kepada kepatuhan MP bertujuan membuktikan elemen pendidikan dalam podcast.

\section{Kerangka Teoritis}

Prinsip kerjasama (PK) oleh Grice (1975) memperlihatkan empat MP yang diyakini merupakan perlakuan standard yang perlu ada semasa komunikasi berlaku. Perlakuan standard ini menurut Davies (2007) ialah anggapan umum bahawa komunikasi tersebut benar dari aspek jumlah pemilikan maklumat, relevan dan dapat mengungkapkan sesuatu yang dapat difahami semasa menghasilkan dan mendengar ujaran. Jadual 1 memaparkan MP oleh Grice (1975) yang disesuaikan daripada perbincangan Zahid (2018).

Jadual 1

Maksim Perbualan

\begin{tabular}{cccc}
\hline $\begin{array}{c}\text { Maksim Kuantiti } \\
\text { (informatif) }\end{array}$ & $\begin{array}{c}\text { Maksim Kualiti } \\
\text { (kebenaran) }\end{array}$ & $\begin{array}{c}\text { Maksim Hubungan } \\
\text { (relevan) }\end{array}$ & $\begin{array}{c}\text { Maksim Cara } \\
\text { (kejelasan) }\end{array}$ \\
\hline a. Pastikan & a. Jangan & a. Pastikan & a. Elakkan \\
sumbangan & bercakap & berkaitan & $\begin{array}{c}\text { kekaburan. } \\
\text { anda }\end{array}$ \\
bersifat & sesuatu & /relevan. & b. Elakkan \\
informatif & /tidak & ketaksaan. \\
seperti yang & benar. & c. Ringkas \\
diperlukan. & b. Jangan & (elakkan \\
b. Jangan & bercakap & lewah). \\
jadikan & sesuatu & d. Pastikan \\
sumbangan & yang & teratur. \\
anda lebih & kurang & & \\
informatif & bukti. & \\
daripada & & & \\
apa yang & & & \\
diperlukan. & & & \\
\hline
\end{tabular}

Nota. Disesuaikan daripada "Logic and Conversation" oleh H. P. Grice, 1975, Syntax and Semantics, Volume 3, 45-47. Academia Press.

Jadual 1 memperlihatkan empat MP dan kata kunci yang diwakilinya, iaitu maksim kuantiti bersifat informatif, maksim kualiti bersifat kebenaran, maksim hubungan 
bersifat relevan, dan maksim cara bersifat kejelasan. Kesemua kata kunci ini mempunyai ciri-ciri yang mesti dipatuhi oleh interlokutor bagi memastikan komunikasi berkesan berlangsung. MP yang diusulkan ini bersifat ideal dan situasi ini tidak selalunya berlaku dalam realiti komunikasi. Sehubungan dengan itu, Grice telah mengenal pasti lima jenis ketidakpatuhan yang berlaku, iaitu pelanggaran, pencabulan, pilihan keluar, penjejasan dan penggantungan maksim. Kelima-lima ketidakpatuhan ini boleh berlaku kepada mana-mana satu MP yang diusulkan. Secara ringkas dipaparkan ketidakpatuhan maksim perbualan oleh Grice yang dibincangkan oleh Zahid (2020, hlm. 39-40):

1. Pelanggaran MP berlaku dengan kesedaran atau pengetahuan interlokutor. Contohnya, dalam ujaran, "Pekan merupakan ibu negeri Johor". Penyataan ini merupakan pelanggaran MP kualiti, iaitu tidak benar dalam konteks maklumat nama ibu negeri.

2. Pencabulan maksim berlaku apabila interlokutor sememangnya berniat atau sengaja tidak mematuhi MP untuk menimbulkan salah faham atau dilakukan atas tujuan tertentu. Contohnya, pembohongan nilai harga barangan yang dibeli, iaitu harga barangan sebenar tidak dimaklumkan bertujuan mengelakkan hukuman atau dipersalahkan. Penyataan sebegini merupakan pencabulan maksim kualiti.

3. Pilihan keluar maksim berlaku apabila interlokutor memilih keluar daripada MP dengan menggunakan frasa yang menyingkirkan atau mengurangkan kesan maksim dan memberikan isyarat kepada penerima misalnya dalam contoh ujaran "saya tidak dapat komen", pada soalan yang diajukan kepadanya.

4. Penjejasan maksim berlaku apabila interlokutor kurang pengetahuan atau kemahiran bertutur sesuatu bahasa, rasa cemas, keterujaan dan sebagainya yang menyebabkan gangguan kepada prestasi interlokutor.

5. Penggantungan maksim berlaku apabila interlokutor menjangkakan ketidakperluan pematuhan pada maksim kerana ia tidak menghasilkan implikatur. Contohnya, upacara pengkebumian dan perkahwinan, lazimnya ujaran pujian diberikan kepada individu yang dirujuk dalam kedua-dua upacara tersebut.

Jadual 2 menunjukkan pula secara ringkas taksonomi Bloom (1956) bagi domain kognitif serta taksonomi Bloom (Krathwohl et al., 1964) bagi domain afektif dan aras-arasnya (Anderson \& Krathwohl, 2001).

Analisis MP Grice akan mencakupi kepatuhan dan ketidakpatuhan MP. Hanya kepatuhan MP dikorelasikan dengan aras-aras dalam domain kognitif dan afektif seperti dalam Jadual 2. Domain kognitif melibatkan perkembangan kemahiran mental dan pemerolehan pengetahuan manakala domain afektif melibatkan perasaan, emosi dan sikap (Hoque, 2016). Dalam konteks ini, korelasi yang dipaparkan merupakan pengabsahan kepada elemen pendidikan yang wujud dalam korpus. Hal ini bererti setiap satu pematuhan MP didapati berkadar selari dengan mana-mana satu aras dalam domain kognitif dan afektif yang dibincangkan. Oleh kerana situasi yang berbeza 
daripada konteks realiti pengajaran dan pembelajaran (PdP) di institusi pengajian, korelasi antara objektif PdP dan hasil pembelajaran dalam medium podcast tidak dinilai.

\begin{tabular}{ll} 
Jadual $\mathbf{2}$ \\
Domain Kognitif dan Domain \\
\hline Domain Kognitif \\
\hline 1. \\
2. Mengingat \\
3. Menahami \\
4. Menganalikasi \\
5. Menilai \\
6. \\
\hline & Mencipta \\
\hline 1. & Menain Afektif \\
2. & Merespons \\
3. & Menilai \\
4. & Mengorganisasi \\
5. & Menghayati
\end{tabular}

\section{Dapatan}

Analisis ujaran soal jawab hos dan $\mathrm{E}$, tetamu undangan terbukti mempunyai papan cerita, iaitu tertib perbincangan topik berkaitan COVID-19. Perbincangan dimulai dengan maklumat umum berkaitan dengan organisma penyebab sehinggalah kepada keperluan anggota masyarakat mengambil tahu akan perkembangan maklumat semasa berkaitan virus Novel ini. Analisis menemukan kepatuhan dan ketidakpatuhan MP dalam episod ini. Kepatuhan MP memperlihatkan korelasi dengan aras-aras tertentu daripada domain kognitif dan afektif taksonomi. Korelasi yang berlaku ini dapat dikenal pasti melalui setiap satu respons yang diberikan oleh $\mathrm{E}$ kepada persoalan yang dibangkitkan. Antara respons yang diberikan misalnya berkaitan istilah umum bagi virus dan bakteria yang berkorelasi dengan aras mengingat dan memahami dalam domain kognitif; serta simptom-simptom COVID-19 yang memperlihatkan korelasi menerima dan menghayati maklumat dalam domain afektif. Hubungan yang berlaku ini membuktikan penyataan Gary (2020) bahawa terdapat kandungan podcast yang bersifat mendidik. Analisis memperlihatkan tidak berlakunya ketidakpatuhan pencabulan, pilihan keluar, penjejasan dan penggantungan.

Perbincangan berkaitan COVID-19 menjadi antara topik yang sentiasa dibincangkan sepanjang tahun 2020 bermula daripada statusnya sebagai epidemik sehinggalah diisytiharkan sebagai pandemik oleh WHO pada 11 Mac 2020 (Intermoutnain Healthcare, 2020; World Health Organization, 2020b). Tahap keseriusan penyakit ini menyebabkan anggota masyarakat mesti disedarkan akan peranan mereka bagi menyekat penularan penyakit ini melalui kaedah memberikan pendidikan. 
Pendidikan yang dimaksudkan ialah penerangan berkaitan dengan penyakit yang baharu sahaja merebak dalam kalangan anggota masyarakat. Dalam konteks \#NoTapis pematuhan kepada MP ternyata memperlihatkan PdP antara seorang doktor dan khalayak pendengarnya melalui medium podcast. PdP disampaikan melalui jawapan kepada soalan yang dikemukakan oleh hos. Tindakan memberikan didikan melalui jawapan kepada soalan yang dikemukakan bukanlah merupakan sesuatu yang baharu. Tindakan yang sama dilakukan oleh Kementerian Kesihatan Malaysia (2020a) dalam segmen berjudul "Soalan Lazim Penyakit Novel Coronavirus (COVID-19)" dalam bentuk dokumen pdf setebal 128 halaman. Spesifik kepada kandungan dokumen ini, soalan bernombor 39 menyatakan peranan anggota masyarakat dalam pencegahan COVID-19 melalui Cegah, Amal, Patuhi, Pantau, iaitu "CEGAH COVID-19" dengan mendidik keluarga serta komuniti dalam kehidupan norma baharu.

Dapatan dipaparkan dalam bentuk jadual dengan setiap satu jadual memuatkan soal jawab yang berlangsung. Terdapat beberapa jadual yang memperlihatkan celahan ujaran yang berlaku antara jawapan-jawapan yang diberikan. Celahan yang tidak relevan berkaitan dengan soalan dipaparkan dengan ruangan yang digelapkan. Sementara celahan yang relevan dipaparkan tanpa pelabelan jenis ujaran (JU). Petunjuk standard singkatan yang digunakan dalam kandungan jadual analisis MP dipaparkan hanya sekali, iaitu selepas Jadual 3. Hal ini bertujuan mengelakkan perulangan maklumat.

Jadual 3 merupakan paparan soal jawab berkaitan maklumat perbezaan istilah virus, microbes dan bakteria dalam bidang perubatan. Soalan pertama yang dikemukakan ini bermanfaat kepada pendengar kerana sering kali istilah ini tidak diketahui secara rinci oleh anggota masyarakat kecuali yang sering kali didengar, iaitu istilah virus dan bakteria yang terbahagi kepada dua, iaitu bakteria baik dan bakteria jahat (Kementerian Kesihatan Malaysia, 2017). Hal yang sebaliknya bagi istilah microbes. Jadual 3 memperlihatkan hos meminta definisi istilah virus, microbes dan bakteria dalam bidang perubatan. Merujuk pada konteks ini hos ternyata telah menyusun maklumat yang dikehendaki dengan jelas. Walau bagaimanapun, sebaliknya telah berlaku pada jawapan E. Pada aras permukaan, jawapan yang diberikan oleh E, PB2IEU2 didapati tidak menurut susunan penjelasan yang diminta oleh hos. E didapati menyusun jawapan yang diberikan bertepatan dengan kepakarannya dalam ilmu perubatan. E menjelaskan bahawa daripada ketiga-tiga istilah yang ditanyakan tersebut, microbes ialah istilah umum yang mewakili kesemua organisma, iaitu virus dan bakteria yang dirujuk oleh hos. Penjelasan oleh E ini mematuhi MPK dan MPQ yang masing-masingnya bersifat informatif dan benar. Hal yang sama berlaku pada penyataan E dalam PB2IEU3 dengan penambahan maklumat yang mematuhi MPQ berkaitan etimologi istilah microbes yang berasosiasi dengan peralatan yang digunakan untuk melihat organisma tersebut. Penjelasan E bagi kedua-dua ujaran PB2IEU2 dan PB2IEU3 juga didapati mematuhi $\mathrm{MPH}$ dan MPC, iaitu masing-masingnya merujuk kepada kerelevanan maklumat dengan isu yang dibincangkan dan penyampaiannya yang jelas dengan penggunaan bahasa kolokial. Dalam usaha E menambah jelas pemahaman maklumat kepada pendengar, E juga didapati melakukan ketidakpatuhan MP apabila mengulang-ulang maklumat yang sama dalam penjelasan yang diberikan. Perulangan maklumat dapat dilihat pada 
PB2IEU3 dan PB2IEU4 berkaitan dengan nama microbe. Ketidakpatuhan yang berlaku pada kedua-dua ujaran ini ialah pelanggaran MPK, iaitu unsur lewah. PB2IEU4 didapati mematuhi MPQ dan MPH.

\section{Jadual 3}

Persoalan Istilah

\begin{tabular}{|c|c|c|c|c|c|c|c|c|c|c|c|}
\hline \multirow[t]{2}{*}{ JU } & \multirow[t]{2}{*}{ PB } & \multirow[t]{2}{*}{ Ujaran } & \multicolumn{4}{|c|}{ Kepatuhan MP } & \multicolumn{5}{|c|}{ Ketidakpatuhan MP } \\
\hline & & & $\mathbf{K}$ & $\mathbf{Q}$ & $\mathbf{H}$ & $\mathrm{C}$ & $\mathbf{L}$ & $\mathbf{V}$ & 0 & J & G \\
\hline $\mathrm{S}$ & PB2IYU3 & ... pertama ... virus, microbes, bakteria ... & $\mathrm{x}$ & $\mathrm{x}$ & $\mathrm{x}$ & $\mathrm{x}$ & $\mathrm{x}$ & $\mathrm{x}$ & $\mathrm{x}$ & $\mathrm{x}$ & $\mathrm{x}$ \\
\hline J & PB2IEU2 & $\begin{array}{l}\text { Microbes ... term general ... organisma ... boleh, ... } \\
\text { dilihat ... alat microscope. }\end{array}$ & $\sqrt{ }$ & $\sqrt{ }$ & $\sqrt{ }$ & $\sqrt{ }$ & $\mathrm{X}$ & $\mathrm{x}$ & $\mathrm{x}$ & $\mathrm{x}$ & $\mathrm{x}$ \\
\hline J & PB2IEU3 & Sebab tu ... panggil ... . Microscope, microbe. & $\mathrm{X}$ & $\sqrt{ }$ & $\sqrt{ }$ & $\sqrt{ }$ & $\sqrt{ }$ & $\mathrm{x}$ & $\mathrm{X}$ & $\mathrm{X}$ & $\mathrm{x}$ \\
\hline J & PB2IEU4 & Atau microscopic organism. ... boleh dilihat ... microscope. & $\mathrm{x}$ & $\sqrt{ }$ & $\sqrt{ }$ & $\mathrm{x}$ & $\sqrt{ }$ & $\mathrm{x}$ & $\mathrm{x}$ & $\mathrm{x}$ & $\mathrm{x}$ \\
\hline J & PB2IEU5 & $\begin{array}{l}\text {... microbe... ada macam-macam .... ... jenis bakteria, .... } \\
\text { jenis virus, ... jenis parasit. }\end{array}$ & $\sqrt{ }$ & $\sqrt{ }$ & $\sqrt{ }$ & $\sqrt{ }$ & $\mathrm{x}$ & $\mathrm{x}$ & $\mathrm{x}$ & $\mathrm{x}$ & $\mathrm{x}$ \\
\hline J & PB2IEU6 & Yang penting ..., virus ... lebih kecil daripada bakteria. & $\sqrt{ }$ & $\sqrt{ }$ & $\sqrt{ }$ & $\sqrt{ }$ & $\mathrm{x}$ & $\mathrm{x}$ & $\mathrm{x}$ & $\mathrm{x}$ & $\mathrm{x}$ \\
\hline & PB2IYU13 & Oh! & $\mathrm{x}$ & $\mathrm{x}$ & $\mathrm{x}$ & $\mathrm{x}$ & $\mathrm{x}$ & $\mathrm{x}$ & $\mathrm{x}$ & $\mathrm{x}$ & $\mathrm{x}$ \\
\hline J & PB2IEU7 & $\begin{array}{l}\text { Lebih kecil. ... sebelum wabak Wuhan ... bingung } \\
\text { mengenai ubat sepertiantibiotik. }\end{array}$ & $x$ & $\sqrt{ }$ & $\sqrt{ }$ & $x$ & $\sqrt{ }$ & $\mathrm{x}$ & $\mathrm{x}$ & $\mathrm{x}$ & $\mathrm{x}$ \\
\hline J & PB2IEU8 & Antibiotik ... untuk ... bakteria. & $\sqrt{ }$ & $\sqrt{ }$ & $\sqrt{ }$ & $\sqrt{ }$ & $\mathrm{x}$ & $\mathrm{x}$ & $\mathrm{X}$ & $\mathrm{x}$ & $\mathrm{x}$ \\
\hline$J$ & PB2IEU9 & $\begin{array}{l}\text {... tidak menangani virus. ... tak bermakna anda batuk, } \\
\text { selsema ... mesti makan antibiotik. }\end{array}$ & $\mathrm{x}$ & $\sqrt{ }$ & $\sqrt{ }$ & $\sqrt{ }$ & $\sqrt{ }$ & $\mathrm{x}$ & $\mathrm{x}$ & $\mathrm{x}$ & $\mathrm{x}$ \\
\hline
\end{tabular}

Petunjuk

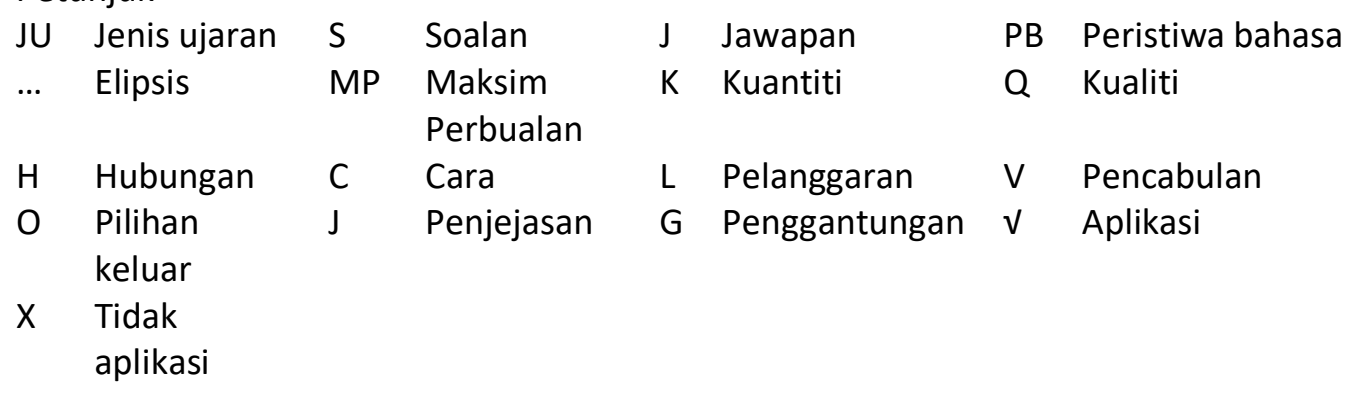

Sehubungan dengan maklumat microbes, E, dalam PB2IEU5 menjelaskan penjenisan microbes, iaitu virus, bakteria dan parasit. E didapati mematuhi keempatempat MP, iaitu masing-masingnya berkaitan informatif, benar, relevan dan disampaikan dengan jelas oleh $\mathrm{E}$ berkaitan kewujudan jenis microbe ini. Penyataan $\mathrm{E}$ disusuli dengan penjelasan bahawa saiz virus yang lebih kecil daripada bakteria dalam PB2IEU6. Maklumat ini penting kerana E membezakan antara dua sifat microbe ini. PB2IEU6 didapati mematuhi keempat-empat MP, iaitu bersifat informatif, benar serta penjelasan E yang relevan dan jelas, iaitu berkesinambungan dengan soalan PB2IYU3 
yang dikemukakan pada peringkat awal walaupun terdapat lima celahan telah berlaku sebelum ini.

Sementara itu, PB2IEU7 memperlihatkan E melakukan pelanggaran MPK kerana mengulang maklumat berkaitan saiz virus. Pelanggaran ini didapati berpunca daripada celahan yang berlaku sebelumnya, iaitu hos mengujarkan kata seruan Oh! dalam PB2IYU13 yang menandakan kehairanan dalam konteks ini. Pelanggaran MPK dalam konteks ini mempunyai fungsi pragmatik penegasan maklumat dan menghapuskan ketidakpastian (Kumar, 2019). E dalam ujaran yang sama kemudiannya menghubungkan maklumat yang disampaikan dengan kekeliruan anggota masyarakat dengan sejenis ubat, iaitu antibiotik. Penyataan ini mematuhi MPQ dan MPH berasaskan pengalaman E sebagai pengamal perubatan apabila berdepan dengan pesakit. Penegasan E dalam PB2IEU8 mematuhi keempat-empat MP manakala PB2IEU9 mematuhi MPQ, MPH dan MPC, iaitu bersifat benar, relevan dan jelas bahawa antibiotik digunakan untuk menangani bakteria dan tidak berkesan dalam menangani jangkitan virus seperti penyakit batuk, selsema dan sebagainya. Penyataan E didapati selari dengan maklumat Kementerian Kesihatan Malaysia (2014) dan hantaran terkini dalam laman Facebook Kementerian Kesihatan Malaysia (2020b) yang menyatakan bahawa $85 \%$ daripada demam dan selsema disebabkan oleh jangkitan virus dan kedua-dua penyakit ini tidak memerlukan antibiotik. E didapati melakukan pelanggaran MPK apabila mengulang maklumat yang sama dalam bentuk parafrasa, iaitu "... tidak menangani virus ..." dalam PB2IEU9.

Sementara itu, Jadual 4 memperlihatkan kesinambungan maklumat berkaitan antibiotik yang disalahgunakan oleh pesakit.

\section{Jadual 4}

Persoalan Antibiotik

\begin{tabular}{|c|c|c|c|c|c|c|c|c|c|c|c|}
\hline \multirow[t]{2}{*}{ JU } & \multirow[t]{2}{*}{ PB } & \multirow[t]{2}{*}{ Ujaran } & \multicolumn{4}{|c|}{ Kepatuhan MP } & \multicolumn{5}{|c|}{ Ketidakpatuhan MP } \\
\hline & & & $\mathbf{K}$ & $\mathbf{Q}$ & $\mathbf{H}$ & C & $\mathbf{L}$ & $\mathbf{v}$ & 0 & J & G \\
\hline $\mathrm{s}$ & PB2IYU14 & Betul ... . . Jadi Dr selalu dapat ni lah. & $\mathrm{x}$ & $\mathrm{x}$ & $\mathrm{x}$ & $\mathrm{x}$ & $x$ & $\mathrm{x}$ & $\mathrm{x}$ & $\mathrm{x}$ & $\mathrm{x}$ \\
\hline \multirow[t]{3}{*}{ J } & PB2IEU10 & Ni masalah yang. & $x$ & $\mathrm{x}$ & $\mathrm{x}$ & $x$ & $\sqrt{ }$ & $\mathrm{x}$ & $x$ & $x$ & $x$ \\
\hline & PB2IYU15 & Pesakit yang minta ... & $x$ & $\mathrm{x}$ & $\mathrm{x}$ & $x$ & $x$ & $\mathrm{x}$ & $x$ & $x$ & $\mathrm{x}$ \\
\hline & PB2IYU16 & Antibiotik. & $\mathrm{x}$ & $x$ & $x$ & $x$ & $x$ & $x$ & $x$ & $x$ & $x$ \\
\hline$J$ & PB2IEU11 & $\begin{array}{l}\text { Antibiotik ... sakit, saya demam. ... batuk, ... } \\
\text { kita menyalahgunakan antibiotik sampai } \\
\text { peluru emas ini tak boleh digunakan. Banyak } \\
\text { tak boleh digunakan untuk melawan } \\
\text { bakteria. }\end{array}$ & $x$ & $\sqrt{ }$ & $\sqrt{ }$ & $\sqrt{ }$ & $\sqrt{ }$ & $x$ & $x$ & $x$ & $x$ \\
\hline
\end{tabular}

Lanjutan daripada isu penggunaan antibiotik dalam pengubatan penyakit, $E$ dalam PB2IEU10 menyatakan masalah yang dihadapi dengan ujaran yang tergantung sifatnya. Ujaran ini memperlihatkan pelanggaran MPC, iaitu kekaburan maklumat kepada pendengar yang tidak mengetahui kesinambungan maklumat yang ingin disampaikan sementelahan pula ujaran tersebut terus diikuti celahan ujaran oleh hos, PB21YU15, celahan tidak relevan dan celahan penyataan antibiotik pada PB21YU16. E dalam PB2IEU11 menjelaskan situasi pesakit yang menyalahgunakan antibiotik untuk 
mengubati penyakit yang berpunca daripada jangkitan virus. Penyakit yang berpunca daripada jangkitan virus antaranya ialah demam biasa, selesema dan bronkitis akut. Sementara itu, penyalahgunaan antibiotik akan menyebabkan berlakunya kerintangan antibiotik, iaitu situasi antibiotik yang hilang keupayaan untuk membunuh bakteria (Kementerian Kesihatan Malaysia, 2014). Maklumat ini dinyatakan oleh E, dalam bahasa kolokial, iaitu "... sehingga peluru emas ini tidak boleh digunakan." dan "Banyak tak boleh digunakan untuk melawan bakteria". Penggunaan bahasa kolokial dengan analogi "peluru emas" untuk antibiotik merujuk kepada sesuatu yang sangat berharga yang fungsinya bersasar mematikan bakteria. Sehubungan dengan itu, "peluru emas" ini seharusnya tidak digunakan secara sewenang-wenangnya. Dalam konteks ini, E mewujudkan situasi bebas gangguan semantik kepada pendengar podcast. Gangguan semantik akan berlaku sekiranya E menggunakan jargon dalam bidang perubatan, iaitu kerintangan antibiotik sepertimana penerangan dalam Kementerian Kesihatan Malaysia (2014) dan laman Facebook Kementerian Kesihatan Malaysia (2020b). PB2IEU11 memperlihatkan pematuhan $\mathrm{MPQ}, \mathrm{MPH}$ dan MPC, iaitu benar, relevan dan jelas berkaitan maklumat yang dinyatakan. Walau bagaimanapun PB2IEU11 memperlihatkan pelanggaran MPK, iaitu perulangan maklumat yang sama, sepertimana kandungan maklumat pada ujaran PB2IEU9 dalam Jadual 3. Perulangan ini dirujuk sebagai unsur lewah dan bertujuan penegasan dan pengesahan maklumat. Menurut Kumar (2019) pengesahan maklumat merupakan antara fungsi pragmatik perulangan dalam tuturan spontan dan dalam konteks ini, E mengesahkan maklumat yang dinyatakan oleh hos dalam PB2IYU15 dan PB2IYU16.

Kesinambungan maklumat seterusnya berkaitan dengan penularan wabak dalam kalangan anggota masyarakat seperti Jadual 5.

\section{Jadual 5}

Persoalan Penularan Wabak

\begin{tabular}{|c|c|c|c|c|c|c|c|c|c|c|c|}
\hline \multirow[t]{3}{*}{ JU } & \multirow[t]{2}{*}{ PB } & \multirow[t]{2}{*}{ Ujaran } & \multicolumn{4}{|c|}{ Kepatuhan MP } & \multicolumn{5}{|c|}{ Ketidakpatuhan MP } \\
\hline & & & $\mathbf{K}$ & $\mathbf{Q}$ & $\mathbf{H}$ & $\mathrm{C}$ & $\mathbf{L}$ & V & 0 & J & G \\
\hline & PB2IEU12 & $\begin{array}{l}\text { Jadi saya akan. Ini andaian yang amat tepat ... } \\
\text { wabak Wuhan ... menular melalui droplets ... } \\
\text { kan ... air ludah kan. }\end{array}$ & $\sqrt{ }$ & $\sqrt{ }$ & $\sqrt{ }$ & $\sqrt{ }$ & $\mathrm{x}$ & $\mathrm{x}$ & $\mathrm{x}$ & $\mathrm{x}$ & $x$ \\
\hline $\mathrm{S}$ & PB2IYU18 & Cecair? & $x$ & $x$ & $\mathrm{x}$ & $\mathrm{x}$ & $\mathrm{x}$ & $\mathrm{x}$ & $x$ & $\mathrm{x}$ & $x$ \\
\hline \multirow[t]{2}{*}{$J$} & PB2IEU13 & Cecair, tak cair. & $\sqrt{ }$ & $\sqrt{ }$ & $\sqrt{ }$ & $\sqrt{ }$ & $\mathrm{x}$ & $\mathrm{x}$ & $x$ & $x$ & $x$ \\
\hline & PB2IRU9 & Air ludah, air ludah. & $\mathrm{x}$ & $\mathrm{x}$ & $\mathrm{x}$ & $\mathrm{x}$ & $\mathrm{x}$ & $\mathrm{x}$ & $\mathrm{x}$ & $\mathrm{x}$ & $x$ \\
\hline \multirow[t]{2}{*}{ J } & PB2IEU14 & $\begin{array}{lllll}\text { Cecair, } \ldots & \text { macam-macam } & \ldots & \text { daripada } \\
\text { badan .... } & & & \end{array}$ & $\sqrt{ }$ & $\sqrt{ }$ & $\sqrt{ }$ & $\mathrm{X}$ & $\sqrt{ }$ & $\mathrm{x}$ & $\mathrm{x}$ & $\mathrm{x}$ & $x$ \\
\hline & PB2IYU19 & $\begin{array}{l}\text { Nangis, hingus dan beberapa beberapa yang } \\
\text { sewaktu dengannya. }\end{array}$ & $\mathrm{x}$ & $\mathrm{x}$ & $\mathrm{x}$ & $\mathrm{x}$ & $\mathrm{x}$ & $\mathrm{x}$ & $\mathrm{x}$ & $\mathrm{x}$ & $x$ \\
\hline \multirow[t]{2}{*}{$\mathrm{J}$} & PB2IEU15 & $\begin{array}{l}\text {... menular daripada droplets ... } \\
\text { mengurangkan penularan... digalakkan untuk } \\
\text { mungkin ... batuk, selsema ... memakai } \\
\text { pelitup udara .... }\end{array}$ & $\mathrm{x}$ & $\sqrt{ }$ & $\sqrt{ }$ & $\sqrt{ }$ & $\sqrt{ }$ & $\mathrm{x}$ & $\mathrm{x}$ & $\mathrm{x}$ & $x$ \\
\hline & PB2IYU20 & Okay, okay. & $\mathrm{x}$ & $x$ & $x$ & $\mathrm{x}$ & $\mathrm{x}$ & $\mathrm{x}$ & $\mathrm{x}$ & $\mathrm{x}$ & $x$ \\
\hline
\end{tabular}

Peristiwa bahasa PB2IEU12 memperlihatkan E memulakan penerangannya dengan ujaran yang tidak gramatis, iaitu ujaran tergantung yang kemudiannya diikuti dengan $E$ 
menyatakan punca penularan wabak dengan frasa "andaian yang amat tepat". Dalam konteks ini, kata "andaian" yang bermaksud anggapan (Dewan Bahasa dan Pustaka, 2015) tidak diklasifikasikan sebagai pelanggaran MPQ kerana semasa temu bual podcast ini berlangsung, COVID-19 masih lagi baharu dalam persekitaran masyarakat dan maklumat yang diperoleh masih belum banyak. Sehubungan itu, penggunaan frasa "andaian yang amat tepat" bersesuaian dengan situasi semasa dan dalam masa yang sama mematuhi MPK kerana bersifat informatif. Penyataan E ini selari dengan konsep penyisian majmuk (Prince et al., 1982; Salager-Meyer, 1995), iaitu berkaitan dengan tahap ketidakpastian mengenai kandungan perkara yang diperkatakan sekali gus juga menggambarkan sejauh mana penglibatan penutur terhadap isu yang diperkatakan dalam komunikasi. PB2IEU12 juga mematuhi MPH dan MPC kerana maklumat yang dibincangkan relevan dan jelas perkongsian maklumatnya berhubung dengan kaedah penularan yang berlaku, iaitu melalui droplets dan air ludah.

Selanjutnya, E menjelaskan dengan lebih spesifik berkaitan soalan hos PB2IYU18 bahawa penularan boleh berlaku melalui cecair dan bukan cecair dalam PB2IEU13 yang sekali gus mematuhi keempat-empat MP yang dibincangkan oleh Grice (1975). Penjelasan E diperkukuh oleh hos dalam PB2IRU9 yang merujuk kepada penjelasan E sebelum ini, iaitu air ludah. Walau bagaimanapun E, dalam PB2IEU14 menambah jelas maklumat ini bahawa konsep cecair yang dirujuk tersebut lebih luas dan umum, iaitu apa-apa sahaja yang dikeluarkan oleh badan dan tidak terhad kepada air ludah. Walaupun E mematuhi MPK, MPQ dan MPH dan memperbetulkan maklumat hos, E didapati tidak mematuhi MPC, iaitu merujuk kepada maklumat yang kabur untuk pengetahuan masyarakat kerana cecair yang dikeluarkan daripada badan manusia tidak dijelaskan dan E didapati tidak menghuraikan frasa "tak cecair" yang dinyatakannya pada PB2IEU13. Bertitik tolak daripada PB2IEU14, hos membuat kesimpulan dalam PB2IYU19 bahawa cecair yang dirujuk ialah seperti air mata, hingus dan sebagainya.

Selanjutnya PB2IEU15 pula, memperlihatkan kaedah menyekat penularan wabak dengan penggunaan pelitup muka. Maklumat ini didapati mematuhi MPQ, MPH dan MPC, iaitu benar, relevan dan jelas walaupun E didapati menggunakan frasa "mungkin" dalam penyataan keperluan memakai pelitup muka kepada individu yang batuk dan selesema. Penggunaan frasa "mungkin" memaparkan konteks yang sama sepertimana PB2IEU12 kerana semasa temu bual berlangsung, maklumat berkenaan COVID-19 belum begitu diketahui umum. Penyataan E dalam konteks ini bertepatan dengan konsep penyisian kebolehlaksanaan perisai (plausibility shields) yang membantu penutur menafikan tanggungjawab berkaitan sesuatu kebenaran dalam ujaran yang dinyatakan (Gribanova \& Gaidukova, 2019). Sementara itu, pelanggaran MPK berlaku kerana $\mathrm{E}$ mengulang maklumat yang sama berkaitan cara penularan dan ini tidak menjejaskan keberkesanan komunikasi (Zahid, 2020) kerana bertujuan penegasan, pengesahan dan penjelasan maklumat.

Perbincangan selanjutnya berkembang kepada persoalan yang spesifik berkaitan virus korona seperti paparan dalam Jadual 6. 


\section{Jadual 6}

Persoalan Virus Korona

\begin{tabular}{|c|c|c|c|c|c|c|c|c|c|c|c|}
\hline \multirow[t]{2}{*}{ JU } & \multirow[t]{2}{*}{ PB } & \multirow[t]{2}{*}{ Ujaran } & \multicolumn{4}{|c|}{ Kepatuhan MP } & \multicolumn{5}{|c|}{ Ketidakpatuhan MP } \\
\hline & & & $\mathbf{K}$ & $\mathbf{Q}$ & $\mathbf{H}$ & $\mathrm{C}$ & $\mathbf{L}$ & V & 0 & J & G \\
\hline s & PB3IYU23 & Virus ni lebih bahaya daripada bakteria? & $\mathrm{x}$ & $\mathrm{x}$ & $\mathrm{x}$ & $\mathrm{x}$ & $\mathrm{x}$ & $x$ & $\mathrm{x}$ & $\mathrm{x}$ & $x$ \\
\hline J & PB3IEU16 & Tidak. & $\sqrt{ }$ & $\sqrt{ }$ & $\sqrt{ }$ & $\sqrt{ }$ & $\mathrm{x}$ & $x$ & $x$ & $x$ & $\mathrm{x}$ \\
\hline $\mathrm{s}$ & PB3IYU24 & Sama juga perangai dia? & $\mathrm{x}$ & $\mathrm{x}$ & $\mathrm{x}$ & $\mathrm{x}$ & $\mathrm{x}$ & $\mathrm{x}$ & $\mathrm{x}$ & $x$ & $x$ \\
\hline \multirow[t]{2}{*}{$J$} & PB3IEU17 & $\begin{array}{l}\text { Virus ... ada macam-macam ... . Ada virus. } \\
\text { Virus korona ni ada macam-macam. } \\
\text { Sekarang ... ni ada } 6 \text { macam. Yang } 4 \text { macam } \\
\text { tu yang selalu kita ada lah, yang batuk, } \\
\text { selsema tu kan. }\end{array}$ & $\sqrt{ }$ & $\sqrt{ }$ & $\sqrt{ }$ & $\sqrt{ }$ & $\sqrt{ }$ & $\mathrm{x}$ & $\mathrm{x}$ & $x$ & $x$ \\
\hline & PB3IYU25 & Okay & $\mathrm{x}$ & $\mathrm{x}$ & $\mathrm{x}$ & $\mathrm{x}$ & $\mathrm{x}$ & $\mathrm{x}$ & $\mathrm{x}$ & $\mathrm{x}$ & $x$ \\
\hline \multirow[t]{2}{*}{$J$} & PB3IEU18 & $\begin{array}{l}\text { Tu semua virus juga. Virus biasa.... yang ni ... } \\
\text { walaupun tak ada ubat untuk } \\
\text { menanganinya.... mereka yang sihat akan ... } \\
\text { sembuhlah. }\end{array}$ & $\sqrt{ }$ & $\sqrt{ }$ & $\sqrt{ }$ & $\sqrt{ }$ & $\sqrt{ }$ & $x$ & $x$ & $x$ & $\mathrm{x}$ \\
\hline & PB3IYU26 & Daya ketahanan diri mereka bagus. & $\mathrm{x}$ & $\mathrm{x}$ & $\mathrm{x}$ & $\mathrm{x}$ & $x$ & $\mathrm{x}$ & $x$ & $\mathrm{x}$ & $x$ \\
\hline$J$ & PB3IEU19 & $\begin{array}{l}\text { Daya ketahanannya. ... ada koronavirus yang } \\
\text { lebih merbahaya. Sebelum novel Koronavirus } \\
\text { ni, kita tahu. }\end{array}$ & $\sqrt{ }$ & $\sqrt{ }$ & $\sqrt{ }$ & $\sqrt{ }$ & $\sqrt{ }$ & $x$ & $x$ & $x$ & $x$ \\
\hline$S$ & PB3IRU13 & Mers? & $x$ & $\mathrm{x}$ & $x$ & $x$ & $x$ & $x$ & $x$ & $x$ & $x$ \\
\hline$J$ & PB3IEU20 & $\begin{array}{l}\text { Sars virus dan juga Mers.... Jadi lepas ni, ... } \\
\text { kita dapati yang baru ni lah. ... dipanggil } \\
\text { Novel.... Novel. }\end{array}$ & $\sqrt{ }$ & $\sqrt{ }$ & $\sqrt{ }$ & $\sqrt{ }$ & $\sqrt{ }$ & $x$ & $x$ & $x$ & $x$ \\
\hline
\end{tabular}

Jadual 6 memperlihatkan E secara ringkas menjawab persoalan hos dalam PB3IYU23 berkaitan tahap bahaya virus korona berbanding dengan bakteria. Jawapan E didapati mematuhi keempat-empat MP. Jawapan tersebut menjadi titik tolak pertanyaan berkaitan sifat virus dan E, dalam PB3IEU17 didapati tidak menjawab soalan tersebut secara langsung sebaliknya menjelaskan tentang bilangan jenis virus. Penyataan jenis-jenis virus ini merupakan jawapan berimplikatur. Bagi penutur natif, implikatur ini didapati mematuhi keempat-empat MP, iaitu bersifat informatif, benar, relevan dan jelas bahawa sifat virus tersebut adalah berbeza. Dapatan ini ternyata selari dengan penemuan Hasan et al. (2020), iaitu penggunaan ujaran berimplikatur ini sering kali berkaitan dengan khalayak sasaran yang merupakan penutur natif. Ujaran yang berikutnya, E menyatakan bahawa sehingga kini terdapat enam jenis virus dan empat daripadanya sering menyerang manusia. Penyataan ini memperlihatkan berlakunya ketidakpatuhan, iaitu pelanggaran MPC dan MPK, iaitu masing-masingnya kerana maklumat yang diberikan kabur, iaitu E mempunyai anggapan bahawa anggota masyarakat telah mengetahui empat jenis virus yang dinyatakan dan ini menyebabkan $\mathrm{E}$ telah tidak membekalkan maklumat yang memadai tentang virus yang dinyatakan tersebut. Sebaliknya, E telah meneruskan penerangan berkaitan virus apabila menerima pakai isyarat hos dalam PB3IYU25, iaitu ujaran Okay yang bermaksud memahami perkara yang dinyatakan oleh E. Lanjutan itu, E dalam konteks ini didapati mengulangi intipati maklumat pada PB3IEU17, "Tu semua virus" dalam PB3IEU18. Tindakan ini merupakan pelanggaran MPK, iaitu kelewahan maklumat berlaku. Perulangan ini menurut Kumar (2019) bertujuan penegasan dan pengesahan maklumat. Sementara itu, kepatuhan keempat-empat MP dalam PB3IEU18 diperlihatkan melalui E menyatakan 
bahawa penyakit ini tidak ada ubatnya dan kesembuhannya bergantung kepada daya ketahanan tubuh manusia. Penyataan E ini selari dengan laporan berita Sarchio (2020). Semasa temu bual ini berlangsung, penyakit COVID-19 masih belum ada vaksinnya namun demikian laporan berita terkini menyatakan bahawa vaksin penyakit ini telahpun ditemui (Roxby, 2020).

Selanjutnya, pelanggaran MPK ditemui pada ujaran awal PB3IEU19 apabila E didapati mengulang maklumat berkaitan ketahanan badan dalam menangani COVID-19, iaitu maklumat yang sama dalam PB3IEU18. Sebaliknya, ujaran PB3IEU19 berikutnya memperlihatkan pematuhan keempat-empat MP apabila $E$ menyatakan bahawa sebelum ini wujud virus korona yang lebih bahaya. Maklumat ini bertepatan fakta, relevan dan jelas selain bersifat informatif yang berimplikatur peringatan bahawa virus yang dibincangkan ini daripada keluarga yang sama dan telah wujud sebelum ini (Hewings-Martin, 2020).

\section{Jadual 7}

Persoalan Simptom Virus

\begin{tabular}{|c|c|c|c|c|c|c|c|c|c|c|c|}
\hline \multirow[t]{2}{*}{ JU } & \multirow[t]{2}{*}{ PB } & \multirow[t]{2}{*}{ Ujaran } & \multicolumn{4}{|c|}{ Kepatuhan MP } & \multicolumn{5}{|c|}{ Ketidakpatuhan MP } \\
\hline & & & $\mathbf{K}$ & $\mathbf{Q}$ & $\mathbf{H}$ & $\mathrm{C}$ & $\mathbf{L}$ & V & o & J & G \\
\hline $\mathrm{s}$ & PB3IRU13 & $\begin{array}{l}\text { Kenapa perkataan Novel tu perlu digunakan? } \\
\text {... menyifatkan apa tu, ciri apa ... tentang } \\
\text { virus tu? }\end{array}$ & $x$ & $x$ & $\mathrm{x}$ & $\mathrm{x}$ & $\mathrm{x}$ & $\mathrm{x}$ & $x$ & $\mathrm{x}$ & $\mathrm{x}$ \\
\hline \multirow[t]{2}{*}{ J } & PB3IEU 21 & $\begin{array}{l}\text { Saya rasa ....mungkin ... sama keluarga dengan } \\
\text { Sars, tetapi unik .... Mungkin ... ada } \\
\text { perbezaan ... simptom-simptomnya ... dia } \\
\text { merebak.... Sars ... simptom-simptom } \\
\text { seperti demam, batuk, selsema .... . Tapi ... } \\
\text { mungkin seseorang ... tak batuk, tak selsema } \\
\text {... mungkin ada virus korona, novel } \\
\text { koronavirus. }\end{array}$ & $\sqrt{ }$ & $\checkmark$ & $\checkmark$ & $\sqrt{ }$ & $x$ & $\mathrm{x}$ & $x$ & $\mathrm{x}$ & $x$ \\
\hline & PBIRU14 & Oh. & $x$ & $x$ & $\mathrm{x}$ & $\mathrm{x}$ & $\mathrm{x}$ & $\mathrm{x}$ & $x$ & $\mathrm{x}$ & $\mathrm{x}$ \\
\hline $\mathrm{s}$ & PB3IYU28 & ... petanda-petanda tu kurang jelas. & $x$ & $\mathrm{x}$ & $\mathrm{x}$ & $\mathrm{x}$ & $x$ & $x$ & $x$ & $\mathrm{x}$ & $\mathrm{x}$ \\
\hline$J$ & PB3IEU22 & Ah. Kurang jelas, kurang jelas. & $x$ & $\checkmark$ & $\checkmark$ & $\sqrt{ }$ & $\sqrt{ }$ & $x$ & $x$ & $\mathrm{x}$ & $x$ \\
\hline \multirow[t]{3}{*}{$\mathrm{S}$} & PBIRU15 & Simptom-simptomnya? & $x$ & $\mathrm{x}$ & $\mathrm{x}$ & $\mathrm{x}$ & $\mathrm{x}$ & $x$ & $x$ & $\mathrm{x}$ & $\mathrm{x}$ \\
\hline & PBIYU29 & $\begin{array}{l}\text { Lebih bahaya sebab dia kira macam silent } \\
\text { killer. }\end{array}$ & $x$ & $\mathrm{x}$ & $\mathrm{x}$ & $\mathrm{x}$ & $x$ & $\mathrm{x}$ & $\mathrm{x}$ & $\mathrm{x}$ & $x$ \\
\hline & PBIRU16 & Tak nampak ah. & $x$ & $\mathrm{x}$ & $\mathrm{x}$ & $\mathrm{x}$ & $x$ & $x$ & $x$ & $\mathrm{x}$ & $x$ \\
\hline J & PB3IEU23 & $\begin{array}{l}\text {...terlalu banyak development..., harus sedar } \\
\text { ataupun aware about all the new } \\
\text { developmentslah. ... setiap hari, ... kena lihat } \\
\text { pada media ... nasihat, ... kriteria ... yang } \\
\text { terbaru ... penyakit ini? }\end{array}$ & $x$ & $\checkmark$ & $\sqrt{ }$ & $\sqrt{ }$ & $\sqrt{ }$ & $x$ & $x$ & $\mathrm{x}$ & $\mathrm{x}$ \\
\hline
\end{tabular}

Perbincangan mengenai korona virus berterusan apabila E dalam PB3IEU20 menambah penyataan maklumat PB3IRU13 bahawa virus korona juga menyebabkan penyakit Sars manakala nama virus terbaharu ialah Novel. Penyataan ini mematuhi keempat-empat $\mathrm{MP}$, iaitu informatif, menepati fakta, relevan dan jelas walau bagaimanapun pelanggaran MPK berlaku apabila $E$, mengulang semula nama virus yang dirujuk dalam ujaran terakhirnya. Perulangan ini bertujuan penegasan maklumat bahawa virus tersebut ialah virus baharu dan kata Novel bersinonim dengan baharu (new). Penamaan virus ini bertitik tolak daripada kewujudannya yang tidak sama seperti virus korona yang 
biasa tersebar dalam kalangan manusia dan menyebabkan penyakit ringan seperti selsema biasa (Centers for Disease Control and Prevention, 2020a).

Penamaan virus ini seterusnya membangkitkan soalan lanjutan berkaitan simptom virus seperti paparan dalam Jadual 7.

Peristiwa bahasa PB3IRU13 memaparkan persoalan kerelevanan nama yang diberi, iaitu istilah novel yang bermaksud baharu kepada virus yang dirujuk. Respons $\mathrm{E}$ dalam konteks ini memperlihatkan penggunaan pengetahuan sedia ada semasa itu, iaitu memaklumkan bahawa virus tersebut berasal daripada keluarga yang sama seperti penyakit SARS dan hanya berbeza daripada aspek simptomnya, iaitu COVID-19 tidak memperlihatkan simptom walaupun sudah dijangkiti. Penyataan E didapati menggunakan kata "mungkin" semasa memberikan penjelasannya dan ini memperlihatkan ketidakyakinan E dengan maklumat yang disampaikan. Penghuraian E tidak diklasifikasikan sebagai pelanggaran MP kerana maklumat penyakit ini masih belum luas tersebar kepada dunia semasa sesi podcast ini berlangsung malahan punca dan simptom penyakit masih terus dikaji dan dibincangkan (Centers for Disease Control and Prevention, 2020b). Penyataan ini didapati sama seperti yang berlaku dalam konteks PB2IEU12, iaitu penyisian kebolehlaksanaan perisai. Sehubungan dengan itu, PB3IEU21 didapati mematuhi keempat-empat MP, iaitu informatif, benar, relevan dan jelas dalam konteksnya. Selanjutnya, jawapan E menjadi titik tolak kepada penyataan PB3IYU28 bahawa simptom penyakit ini tidak jelas yang kemudiannya diperkukuh oleh $\mathrm{E}$ dalam PB3IEU22. Peristiwa bahasa PB3IEU22 memperlihatkan E mematuhi MPQ, MPH, MPC dan sekali gus melakukan pelanggaran MPK kerana mengulang penyataan "kurang jelas". Selanjutnya, E juga didapati memberikan maklum balas dalam PB3IEU23 kepada penyataan hos dalam PBIRU15 dan PBIYU29 berkenaan tahap bahaya penyakit ini yang tidak dapat dikenal pasti simptomnya. Sama seperti PB3IEU22 penyataan E ini didapati mematuhi MPQ, MPH dan MPC dan sekali gus melakukan pelanggaran MPK apabila menghuraikan keperluan mengikuti perkembangan dari semasa ke semasa berkaitan simptom penyakit ini secara lewah. Sementara itu kepatuhan MP yang ditemui berkorelasi dengan domain kognitif dan afektif (rujuk Jadual 2) yang masing-masingnya berkaitan antaranya dengan pengetahuan dan sikap. Pengetahuan merujuk kepada ilmu yang harus dimiliki; dan sikap pula merujuk kepada perlakuan dan pandangan terhadap isu yang dibincangkan, iaitu COVID-19. "Pelajar" dalam konteks podcast \#NoTapis dididik untuk mengadaptasi kehidupan norma baharu. Dapatan analisis ini dipaparkan dalam Jadual 8. 
Jadual 8

Korelasi Pematuhan MP: Domain Kognitif dan Afektif

\begin{tabular}{|c|c|c|c|c|c|c|c|c|c|c|c|c|c|c|}
\hline \multirow[t]{2}{*}{ PB } & \multirow[t]{2}{*}{ PMP } & \multirow[t]{2}{*}{$P$} & \multicolumn{6}{|c|}{ Aras Domain Kognitif } & \multirow[t]{2}{*}{$P$} & \multicolumn{5}{|c|}{ Aras Domain Afektif } \\
\hline & & & 1 & 2 & 3 & 4 & 5 & 6 & & 1 & 2 & 3 & 4 & 5 \\
\hline PB2IEU2 & $\mathrm{KQHC}$ & 1 & $v$ & $\mathrm{~V}$ & $v$ & V & $x$ & V & 1 & $v$ & $v$ & $x$ & $x$ & $x$ \\
\hline PB2IEU5 & & 1 & $v$ & $\mathrm{~V}$ & V & V & $x$ & V & 2 & 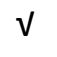 & $x$ & $x$ & $x$ & $x$ \\
\hline PB2IEU6 & & 1 & $\sqrt{ }$ & $\mathrm{V}$ & V & $\mathrm{V}$ & $x$ & V & 2 & $v$ & $x$ & $x$ & $x$ & $x$ \\
\hline PB2IEU8 & & 1 & $v$ & $\mathrm{~V}$ & V & $\mathrm{V}$ & $x$ & $\mathrm{~V}$ & 1 & $v$ & $v$ & $x$ & $x$ & $x$ \\
\hline PB2IEU9 & & 1 & $\sqrt{ }$ & $\mathrm{V}$ & V & V & $x$ & $\mathrm{~V}$ & 3 & $v$ & $v$ & V & v & v \\
\hline PB2IEU11 & & 2 & $v$ & $\mathrm{~V}$ & V & $\mathrm{V}$ & $x$ & $x$ & 3 & $v$ & $v$ & $\mathrm{~V}$ & v & $v$ \\
\hline PB2IEU12 & & 3 & $v$ & $\mathrm{~V}$ & $x$ & $x$ & $x$ & $x$ & 4 & $v$ & $v$ & $\mathrm{~V}$ & v & $x$ \\
\hline PB2IEU13 & & 3 & $v$ & $\mathrm{~V}$ & $X$ & $x$ & $x$ & $x$ & 1 & $v$ & $v$ & $x$ & $x$ & $x$ \\
\hline PB3IEU16 & & 4 & $v$ & $x$ & $x$ & $x$ & $x$ & $x$ & 1 & $v$ & $v$ & $x$ & $x$ & $x$ \\
\hline PB3IEU17 & & 3 & $v$ & $\mathrm{~V}$ & $x$ & $x$ & $x$ & $x$ & 1 & $v$ & $v$ & $x$ & $x$ & $x$ \\
\hline PB3IEU18 & & 5 & $v$ & $\mathrm{~V}$ & V & $x$ & $x$ & $\mathrm{~V}$ & 1 & $v$ & $v$ & $x$ & $x$ & $x$ \\
\hline PB3IEU19 & & 3 & $v$ & $\mathrm{~V}$ & $x$ & $x$ & $x$ & $x$ & 1 & $v$ & $v$ & $x$ & $x$ & $x$ \\
\hline PB3IEU20 & & 3 & $v$ & $\mathrm{~V}$ & $x$ & $x$ & $x$ & $x$ & 5 & $v$ & 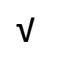 & V & $x$ & $x$ \\
\hline PB3IEU21 & & 1 & $v$ & $\mathrm{~V}$ & V & V & $x$ & V & 3 & $v$ & $v$ & $V$ & V & V \\
\hline PB2IEU14 & $\mathrm{KQH}$ & 3 & $\mathrm{~V}$ & $\mathrm{~V}$ & $X$ & $x$ & $x$ & $x$ & 1 & $\mathrm{~V}$ & $\mathrm{~V}$ & $x$ & $x$ & $x$ \\
\hline PB2IEU3 & $\mathrm{QHC}$ & 3 & $\mathrm{~V}$ & $\mathrm{~V}$ & $x$ & $x$ & $x$ & $x$ & 2 & $\mathrm{~V}$ & $x$ & $x$ & $x$ & $x$ \\
\hline PB2IEU15 & & 6 & $v$ & $\mathrm{~V}$ & V & $x$ & $x$ & $x$ & 4 & $v$ & $v$ & $v$ & V & $x$ \\
\hline PB3IEU22 & & 4 & $v$ & $x$ & $x$ & $x$ & $x$ & $x$ & 1 & $v$ & $v$ & $x$ & $x$ & $x$ \\
\hline PB3IEU23 & & 6 & $v$ & $\mathrm{~V}$ & V & $x$ & $x$ & $x$ & 4 & $v$ & $v$ & $v$ & V & $x$ \\
\hline PB2IEU4 & $\mathrm{QH}$ & 5 & $\mathrm{~V}$ & $\mathrm{~V}$ & $\mathrm{~V}$ & $x$ & $x$ & $\mathrm{~V}$ & 2 & $\mathrm{~V}$ & $x$ & $x$ & $x$ & $x$ \\
\hline PB2IEU7 & & 3 & $v$ & $\mathrm{~V}$ & $x$ & $x$ & $x$ & $x$ & 2 & $\mathrm{~V}$ & $x$ & $x$ & $x$ & $x$ \\
\hline \multicolumn{15}{|l|}{ Petunjuk } \\
\hline PMP Pem & uhan I & & & & & & $r$ & & & & & & & \\
\hline
\end{tabular}

Korelasi pematuhan MP memperlihatkan beberapa pola, iaitu enam pola dan lima pola masing-masingnya merujuk kepada domain kognitif dan afektif. Aras domain kognitif dan domain afektif memperlihatkan kombinasi aras yang pelbagai. Dapatan analisis menemukan bahawa pematuhan MP sentiasa berkorelasi dengan aras paling rendah bagi kedua-dua domain, iaitu aras 1 masing-masingnya merujuk kepada mengingat dan menerima. Aras tertinggi untuk domain kognitif ialah aras 6, iaitu mencipta yang merujuk kepada proses mengintegrasi maklumat manakala aras tertinggi domain afektif ialah aras 5 yang merujuk kepada menghayati. Dapatan ini juga memperlihatkan kewujudan kepelbagaian pola PMP seperti dalam Jadual 8, iaitu PB yang dianalisis memperlihatkan kerencaman aras kognitif dan afektif yang diaplikasi. Hal ini berkaitan dengan objektif episod podcast yang bertujuan mendidik khalayak pendengarnya dengan mengemukakan pelbagai bentuk soalan. MP yang berelemen pendidikan ini ternyata telah mendidik khalayak pendengar podcast tentang persoalan COVID-19 yang masih baharu dalam kalangan anggota masyarakat. Dapatan ini 
membuktikan penyataan oleh Hoque (2016) bahawa PdP merupakan satu proses yang dimulakan daripada aras yang rendah kepada aras yang tinggi. Namun demikian, pematuhan MP tidak memperlihatkan korelasi dengan aras 5, iaitu menilai dalam domain kognitif kerana pendengar podcast hanya menerima maklumat yang diberikan oleh E. Proses menilai maklumat tidak berlaku kerana pendengar mempunyai kepercayaan akan wibawa seorang doktor yang diundang dalam podcast tersebut. Dalam konteks \#NoTapis, E memberikan pelbagai maklumat berkenaan COVID-19 bermula dengan maklumat umum berkaitan penggunaan istilah sehinggalah kepada cara mengekang penularannya. Pemerolehan pengetahuan dan sikap yang ditekankan dalam maklumat \#NoTapis telah menyediakan pendengar mereka akan situasi semasa yang melanda negara di seluruh dunia. Lanjutan itu, E yang bertindak sebagai seorang "guru" dalam konteks ini perlu menyampaikan maklumat dengan bahasa kolokial bagi memastikan "pelajar" daripada pelbagai latar belakang pengetahuan, bidang, taraf akademik, umur dan sebagainya mendapat manfaat daripada penerangan yang dilakukan.

\section{Perbincangan}

Pematuhan MP yang berkorelasi dengan elemen pendidikan memperlihatkan E mempermudah penerangannya dalam temu bual dengan penggunaan bahasa kolokial. Bahasa kolokial ialah jenis tuturan tidak formal yang digunakan antara rakan dan orang lain dalam situasi yang mementingkan empati, hubungan atau keakraban (Richards \& Schmidt, 2002). Tindakan ini tentulah bertitik tolak daripada khalayak sasaran podcast yang pelbagai latar belakang. Tindakan ini juga ternyata selari dengan matlamat podcast \#NoTapis yang antara lainnya bertujuan mendekati komuniti muda Melayu. Sehubugan itu, mempermudah penerangan berkaitan topik berkaitan perubatan dan isu semasa yang belum tersebar luas memerlukan penerangan yang memudahkan proses pemahaman dan penerimaan pengetahuan. Pematuhan MP yang berkorelasi dengan elemen pendidikan ini menepati aras domain kognitif dan afektif dalam taksonomi Bloom bersesuaian dengan objektif podcast episod ini yang bertujuan mendidik khalayaknya. Dalam konteks ini, E misalnya menggunakan frasa "peluru emas" bagi merujuk kepada fungsi, nilai dan keberkesanan antibiotik dalam membunuh bakteria. Penerangan kegagalan "peluru emas" dalam konteks ini bertujuan menggantikan frasa kerintangan antibiotik seperti dalam penerangan Kementerian Kesihatan Malaysia (2014). Dalam konteks ini, E mengelakkan berlakunya gangguan semantik dalam komunikasi. Gangguan semantik ialah penggunaan slanga, jargon atau bahasa yang khusus oleh seseorang atau kumpulan penutur yang menyebabkan ketidakfahaman berlaku pada individu yang dilawan bicara kerana kata atau frasa yang digunakan itu tidak mempunyai makna bagi individu yang berada di luar skop bidang, kumpulan atau penggunanya (West \& Turner, 2010).

Ketidakpatuhan MP yang berlaku, iaitu perulangan maklumat dianggap satu keperluan bertujuan mempertegas maklumat yang disampaikan (Kumar, 2019) dan ini juga kerap berlaku dalam proses PdP. Perulangan maklumat juga bertujuan menambah 
jelas maklumat (Zahid, 2020). Sementara itu, ketidakpatuhan MP pada aras permukaan dengan penggunaan frasa "andaian" dan "mungkin" sebenarnya didapati tidak berlaku kerana maklumat berkenaan COVID-19 masih baharu semasa itu. Penerangan yang diberikan didapati mematuhi MP, iaitu informatif, benar, relevan dan jelas. Dalam konteks ini E bertindak menghindarkan dirinya daripada bebanan dipersalahkan dengan mengaplikasi strategi kebolehlaksanaan perisai (Gribanova \& Gaidukova, 2019) dan penyisian majmuk (Prince et al., 1982; Salager-Meyer, 1995) sekiranya maklumat yang diberikannya tidak tepat kerana $\mathrm{E}$ hanya bersandar pada maklumat terhad yang ada semasa itu.

\section{Kesimpulan}

Analisis yang dilakukan bertujuan mengenal pasti kepatuhan serta ketidakpatuhan MP dan membincangkan korelasi pematuhan MP dengan elemen pendidikan. Objektif ini bertitik tolak daripada pandangan Gary (2020) bahawa podcast bersifat mendidik. Analisis hanya melimitkan tiga data PB kerana dapatan kepatuhan dan ketidakpatuhan MP yang hampir sama dalam semua kajian sebelum ini. Lanjutan itu limitasi ini bertujuan menganalisis data pada sisi yang lain, iaitu korelasi kepatuhan MP dengan taksonomi Bloom bagi domain kognitif dan afektif. Kepatuhan MP bertitik tolak daripada tema episod yang berkaitan dengan bidang perubatan manakala ketidakpatuhan berlaku kerana unsur lewah, iaitu perulangan maklumat dan celahan yang dilakukan oleh hos. Perulangan maklumat didapati bertujuan untuk penegasan dan pengesahan maklumat. Akibat perbezaan maklumat semasa yang berpunca dari tempoh penyiaran episod, terdapat maklumat yang disampaikan dengan menggunakan kata "andaian" dan "mungkin". Penggunaan kedua-dua kata ini tidak diklasifikasikan sebagai ketidakpatuhan sebaliknya dirujuk sebagai penyisian majmuk dan penyisian kebolehlaksanaan perisai. Kepatuhan MP didapati senantiasa berkorelasi dengan aras paling rendah domain kognitif dan afektif. Implikasi kajian ini memperlihatkan elemen pendidikan dapat dan boleh disampaikan dalam pelbagai medium sesuai dengan kecanggihan teknologi semasa. Disyorkan pada masa depan, data dan isu yang bersifat kontemporari dianalisis dengan gabungan pendekatan atau teori bagi mewujudkan kajian bersifat multidisiplin.

\section{Rujukan}

\#NoTapis. (2020, Februari 1). Dr Elly Sabrina - Kupas wabak koronavirus Wuhan [Audio podcast]. https://open.spotify.com/episode/0WLh36otEeowT4pWbEL6gV?si=UKU3Aj3sS
Advanced
Media
Institute.
(2020).
Storyboarding.

https://multimedia.journalism.berkeley.edu/tutorials/starttofinish-

storyboarding 
Aisya, N., \& Fitrawati, F. (2019). An analysis of flouting of maxim performed by politician guests in Mata Najwa talk show in the episode of adu lantang jelang penentuan and babak akhir Pilpres. E-Journal English Language and Literature, 8(4), 42-55.

Anderson, L. W., \& Krathwohl, D.R. (Eds.). (2001). A taxonomy for learning, teaching, and assessing: A revision of Bloom's taxonomy of educational objectives. Longman.

Awwad, A. S., Ayasreh, A. M., Ayasrah, N. M., \& Al-Sabti, N. (2019). Interpretations of the Gricean conversational maxims violations. International Journal of Applied Engineering Research, 14(22), 4100-4104.

Bloom, B. S. (1956). Taxonomy of educational objectives: The classification of educational goals (Cognitive domain, Vol. Handbook I). Mckay.

Krathwohl, D. R., Bloom, B. S., \& Masia, B. B. (1964). Taxonomy of educational objectives: The classification of educational goals (Affective domain, Vol. Handbook II). David McKay.

Centers for Disease Control and Prevention. (2020a). COVID-19: Frequently asked questions. https://www.cdc.gov/coronavirus/2019-ncov/faq.html

Centers for Disease Control and Prevention. (2020b). COVID-19: Symptoms. https://www.cdc.gov/coronavirus/2019-ncov/symptoms-testing/symptoms.html

Crystal, D. (2008). A dictionary of linguistics and phonetics. (6th ed.). Blackwell Publishing.

Davies, B. L. (2007). Grice's cooperative principle: Meaning and rationality. Journal of Pragmatics, 39, 2308-2331.

Dewan Bahasa dan Pustaka. (2015). Andaian. In Kamus dewan (4th ed.). Dewan Bahasa dan Pustaka.

Dictionary.com. (2020). Podcast. In Dictionary.com. https://www.dictionary.com/browse/podcast

Gary, C. (2020). What is a podcast? An explanation in plain English. https://www.thepodcasthost.com/listening/what-is-a-podcast/

Gribanova, T. I., \& Gaidukova, T. M. (2019). Hedging in different types of discourse. Training, Language and Culture, 3(2), 85-99.

Grice, H. P. (1975). Logic and conversation. In Cole, P \& Morgan, J. L. (Eds.), Syntax and semantics (Vol. 3) Speech Acts (pp. 41-58). Academic Press.

Hamani, T., \& Puluhulawa, Y. (2019). Pragmatics analysis of maxim flouting done by the main characters in Kungfu Panda movie by Jonathan Aibel \& Glenn Berger. BRITISH, Jurnal Bahasa Dan Sastra Inggeris, 8(1), 16-26.

Hasan, N., Hamzah, Z. A. Z., Yaakob, N. A., \& Husin, F. (2020). Eksploitasi maksim Grice lambang kehalusan berbahasa masyarakat Melayu: Analisis dalam filem Dayang Senandong (1965). International Journal of the Malay World and Civilisation, $8(2), 25-39$.

Hewings-Martin, Y. (2020, April 10). How do SARS and MERS compare with COVID-19? https://www.medicalnewstoday.com/articles/how-do-sars-and-mers-comparewith-covid-19 
Hoque, M. E. (2016). Three domains of learning: Cognitive, affective and psychomotor. The Journal of EFL Education and Research (JEFLER), 2(2), 45-52.

Intermoutnain Healthcare. (2020, April 2). What's the difference between a pandemic, an epidemic, endemic, and an outbreak? https://intermountainhealthcare.org/blogs/topics/live-well/2020/04/whats-thedifference-between-a-pandemic-an-epidemic-endemic-and-an-outbreak

Kementerian Kesihatan Malaysia. (2014). Amalan terbaik antibiotik. http//:www.myhealth.gov.my/ amalan terbaik antibiotik

Kementerian Kesihatan Malaysia. (2017). Usus sihat: Peranan diet anda. http://www.myhealth.gov.my/usus-sihat-peranan-diet-anda/

Kementerian Kesihatan Malaysia. (2020a). Soalan lazim penyakit Coronavirus (Covid-19). http://www.myhealth.gov.my/wp-content/uploads/SOALAN-LAZIM-COVID19.pdf

Kementerian Kesihatan Malaysia. (2020b). Antibioktik: Perlu ke? https://www.facebook.com/kementeriankesihatanmalaysia

Kumar, D. Z. (2019). Pragmatic functions of repetitions in spontaneous spoken dialect discourse. Dialectologia et Geolinguistica, 27(1), 123-141.

Mcgivern, A. (2020). What is a podcast? Definition and meaning of podcast. https://www.podcasthero.com/what-is-a-podcast/

Muhammad, A. A., \& Karim, H. A. (2019). An analysis of Grice's cooperative principles in some selected English TV interviews. Journal of University of Garmian, 6(2), 444455.

Patterson, L. (2006). The technology underlying. Computer, 39(10), 103-105. https://www.researchgate.net/publication/2961624_The_Technology_Underlyin g_Podcasts

Prince, E., Bosk, C., \& Frader, J. (1982). On hedging in physician-physician discourse. In J. Di Pietro. (Ed.), Linguistics and the professions (pp. 83-97). Ablex.

Pusat Rujukan Persuratan Melayu. (2020). Audio siar. In Dewan bahasa dan pustaka. http://prpmv1.dbp.gov.my/

Richards, J. C. \& Schmidt, R. (2002). Dictionary of language teaching and applied linguistics (3rd ed.). Pearson Education Limited.

Roxby, P. (2020). Russian COVID vaccine shows encouraging results. https://www.bbc.com/news/health-54905330

Salager-Meyer, F. (1995). I think that perhaps you should: A study of hedges in written scientific discourse. The Journal of TESOL France, 2(2),127-143.

Sarchio, S. N. E. (2020). 'Imuniti kelompok' kawal, putuskan rantaian jangkitan. https://www.bharian.com.my/kolumnis/2020/12/761028/imuniti-kelompokkawal-putuskan-rantaian-jangkitan

SPH Media Solutions. (2019). Tap into Berita Harian's podcast \#NOTAPIS. https://www.imsph.sg/tap-into-berita-harians-podcast-notapis/

West, R., \& Turner, L. H. (2010). Introducing communication theory: Analysis and application. McGraw-Hill Higher Education. 
World Health Organization. (2020a). Naming the coronavirus disease (COVID-19) and the virus that causes it. https://www.who.int/emergencies/diseases/novelcoronavirus-2019/technical-guidance/naming-the-coronavirus-disease-(covid2019)-and-the-virus-that-causes-it

World Health Organization. (2020b). WHO Director-General's opening remarks at the media briefing on COVID-19-11 March 2020. https://www.who.int/directorgeneral/speeches/detail/who-director-general-s-opening-remarks-at-the-mediabriefing-on-covid-19---11-march-2020

Zahid, I. (2018). Analisis maksim perbualan Grice dalam soal jawab TV3. Issues in Language Studies, 7(2), 16-35.

Zahid, I. (2020). Ketidakpatuhan maksim perbualan dan komunikasi berkesan dalam soal rakyat. Issues in Language Studies, 9(2), 33-51. 